\title{
Listening To The Land Where The Buffalo Roamed
}

\author{
By Thad Box
}

$\mathrm{A}$ merica's rangelands were always grazed. Although our virgin rangelands did not have cattle on them, they had plant-eating animals for as long as we have evidence. Rangelands evolved with grazing.

Pre-history teases us with tidbits. We know there were plant-eating dinosaurs. Pollen tells us kinds of plants. The fossil record gets better after the last ice age. We know there were little horses and giant bisons in abundance. And that many grasses and shrubs were similar to the ones we have today.

Still, we have little record of grazing effect. We know not if overgrazing existed or how it changed evolving rangelands. Paleo-biologists argue over the different kinds of animals that used the Great Plains and the Great Basin. But we know grazing was natural on all virgin rangelands.

Our first recorded history of American rangelands is in journals of early explorers, usually adventurers and soldiers with little scientific training. The medical officer often became the interpreter of natural history. There is nothing written by ecologists or range managers; such people did not exist. The main items recorded were the land's ability to provide forage for expedition horses and wild animals for human survival.

Spanish explorers gave us the first descriptions of virgin rangelands. And arguably the only description. They brought with them a new kind of grazer, domestic livestock, destined to change the landscape. Descriptions vary from ranges with grass touching saddle stirrups to vast lands so closely grazed there was no feed for horses. In some areas availability of wildlife was plentiful; in others, explorers went days without sighting anything for food.

At best, the early journals are snapshots in time and space. But they are consistent in a few areas: Pristine rangelands were highly variable. All were grazed or browsed by some kind of animals. Density of animals varied, both spatially and seasonally. Native people and wild animals were concentrated around water sources. With the exception of turkeys, few animals were "domesticated."

Spanish records, including five-hun- dred-year histories of settlement in New Mexico and California give the earliest insight into American rangelands. Largely, they remain an untapped treasure buried in archives of Mexican churches. Many scientists lack language and archival skills to access them.

English records of pristine rangelands are recent, mostly less than 150 years old. The first, like the Spanish records, are those of explorers and military expeditions. They, too, show virgin rangelands as highly varied and universally grazed.

Those in the "great American prairie," had dense sod of tall grasses. Beautiful flowers raised colorful heads seasonally. Specimens of tall grasses were collected and sent to botanists for classification. Big

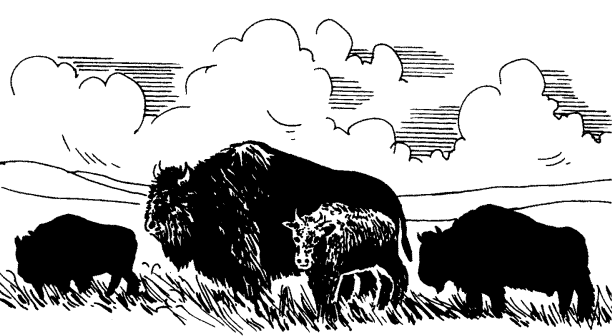

bluestem, little bluestem, Indiangrass, and switchgrass received Latin names and were recognized as the "big four" of a province that covered much of America's mid-west. The sod was often too dense to cut with a plow. That "province" is now grainfields of America's breadbasket. Rangelands exist only as protected remnants.

As explorers went west, they found decreasing rainfall, shorter grasses and dry shrublands. New areas were described as short-grass plains, buffalo grass deserts, and America's great "Zahara." Capt. Marcy, trying to find a route from $\mathrm{Ft}$. Smith, Arkansas to Santa Fe wrote: "When we were upon the high table land, a view presented itself as boundless as the ocean. Not a tree, shrub, or any other object, animate or inanimate, relieved the dreary monotony of the prospect; it was a vast illimitable expense of desert prairie-the dreaded "Llano Estacado" of New Mexico. He went on to say that the only herbage was a "short buffalo grass" and that "all animals appear to shun it."

Yet records from other explorers, hide tanners, and military expeditions sent to pacify Indians show pristine ranges grazed by huge herds of animals. Exact numbers are disputed, but there may have been as many as 50 million bison and another 100 million deer, pronghorn, elk, bighorn sheep, and mountain goats grazing virgin American ranges. Elk, now largely a mountain animal, ranged widely. Bison and deer were everywhere.

The coming of the camera in the late $19^{\text {th }}$ century left a visual record of some pristine ranges. Many "virgin" lands were heavily used when the first military missions arrived. Photos at Miles City, Montana show heavily grazed grasslands, extensive buffalo wallows, and bisontrampled stream banks. Photographs from the Black Hills of Dakota show open savannahs instead of dense pines. Pictures along the U. S.-Mexican border show desert grasslands where creosote bush now grows. Like the written records, they show America's pristine rangelands as highly variable and all grazed. In addition, virgin ranges appear much more open than they are today.

Then bison were killed. Most were shot by contract hunters funded by the military as the most effective way to control Indians. Settlers moved into the prairie and found ways to turn its sod. Railroads poked their way through virgin grasslands and deserts. With killing of the buffalo, most rangelands were without a major grazer. Their evolution was interrupted. But not for long. The Mooar brothers, contract buffalo killers hired by the army, arrived on the southern Great Plains in 1873. By 1894, domestic cattle were dying by thousands on overgrazed ranges where rifles removed the buffalo.

One scene in Andy Adam's "Log of a Cowboy" has a grizzly bear, somewhere in the northern Great Plains, stand and sniff the air. She smells an approaching trail herd from Texas. America's rangelands had not been "virgin" since the Spanish brought horses, sheep and cattle five hundred years ago. The air the grizzly smelled carried the aroma of change; it also announced the need for the profession of range management. 